\title{
Engine Emissions and Performances with Alternative Biodiesels: A Review
}

\author{
A. E. Pillay (Corresponding author) \\ Department of Chemistry, The Petroleum Institute \\ PO Box, 2533, Abu Dhabi, UAE \\ Tel: 971-2607-5417Ｅ-mail: apillay@pi.ac.ae
}

S. C. Fok, M. Elkadi, S. Stephen, J. Manuel, M. Z. Khan \& S. Unnithan

The Petroleum Institute

PO Box, 2533, Abu Dhabi, UAE

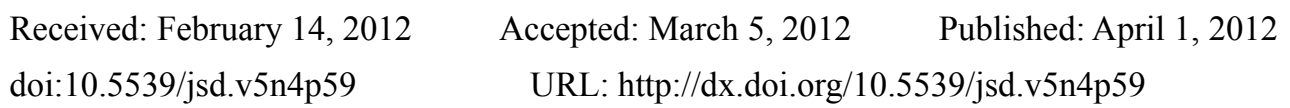

The research is financed by PI-Research Initiation Grant

\begin{abstract}
Smoke opacity, $\mathrm{CO}, \mathrm{NO}_{\mathrm{x}}$ and other engine emissions can vary appreciably with the use of biodiesels obtained from different feedstock. Biofuel density, viscosity and bulk modulus are linked to engine performance and emissions. This paper represents an up-to-date review of engine performances and emissions with biodiesels derived from different feedstock and conventional diesel. The data indicate that biodiesel is an attractive renewable alternative fuel for diesel engines in terms of environmental benefits. Physical and chemical properties of biodiesels can have significant effects on the combustion process, which will impact on the engine performance and emissions. Based on this information, major issues in the search for suitable ingredients and processes to produce quality biodiesels have been presented. The study is of interest to sustainable development.
\end{abstract}

Keywords: Biodiesel, Viscosity, Calorific value, Cetane number, BSFC, Stoichiometric ratios

\section{Introduction}

Interest in biodiesel as an alternative engine fuel has widely increased globally due to political, financial, and environmental reasons. After the oil crisis in the 1970s, many non-oil producing countries initiated efforts to lessen their dependency on fossil fuels by encouraging the development of alternative energy sources such as the production of biodiesel using locally available oil bearing crops. Investors were tempted by the potential returns of investments in these ventures. Feedstock costs constitute the major part of the biodiesel production expenses. By converting unutilized agricultural land to produce high oil-yield crops that are cheap, abundant and can be grown rapidly without restricted growing seasons, analysts believed that the economical production of biofuels for domestic consumption could not only be sustained, but could also be also profitable. This is based on the assumption that the price of biofuels will progressively increase with time owing to the continuous depletion of the limited available fossil fuel reserves and the growing demand for energy. Driven by potential financial gains, the derivation of biodiesels has gained much attention. Extensive research has been conducted on the extraction of biodiesels from different feedstock and the characteristics of biodiesels of different origins on engine performances and emissions have become topics of increasing importance.

To date, hundreds of oil bearing crops have been identified. Among them, oils from rapeseed, cottonseed, sunflower, soybean, and palm are generally considered to be among the top contenders for use in diesel engines (Goering et al., 1982). Although these plant oils can be directly used in diesel engines, they are sensitive to cold weather and start to gel as temperature decreases. This causes clogging of filters, sticking of pistons, jamming of valves, rapid wearing and contamination of lubricating oil. One way to overcome these problems is to process the plant oils to biodiesels. Biodiesel can be derived from a variety of animal and vegetable oils (Ozsezen \& Canakci, 2010; Buyukkaya, 2010; Aydin \& Bayindir, 2010; Celikten et al., 2010; Sayin, 2010; Wu et al., 2009; Lin \& Li, 2009; Qi et al., 2009; Lin et al., 2009; Raheman \& Ghadge, 2007; Rakopoulos et al., 2006; Usta, 2005; Ilkilic \& Yucesu, 2005; Rodjanakid \& Charoenphonphanich, 2004; Kalam \& Masjuki, 2002; Masjuki et al., 1997; 
Abdul Aziz et al., 2005; Singh \& Singh, 2010; Hossain \& Davies, 2010). The chemical basis of vegetable oils, regardless of their origins, is triglyceride, which consists of glycerol and three carboxylic or fatty acids. A common method to generate biodiesel involves the transesterification of the triglycerides with the help of a catalyst (Singh \& Singh, 2010) to produce alkyl monoesters of chained fatty acids that have comparable properties to that of conventional diesel. Glycerol becomes a by-product of this chemical reaction that must be removed by separation processes.

The physicochemical properties of the biodiesel produced would logically depend on the feedstock used. Table 1 summarizes the properties of some of these feedstock oils and biodiesels. The quantity and quality of the oil generated from the same plant species may not be exactly the same and can vary depending on cultivation methods, soil conditions, weather, plant parts used and processing technologies. The data in Table 1 show that for rapeseed oils, the density can vary from 0.872 to $0.920 \mathrm{~g} / \mathrm{cm}^{3}$ while the viscosity can change from 11 to 39 $\mathrm{mm}^{2} / \mathrm{s}$, with the cetane number ranging from 37.6 to 39.0. The properties of oils from different crops can vary due to different fatty acid contents and different amounts of impurities such as alkalis and phosphorus. For soybean oils, the density $\left(0.914\right.$ to $0.925 \mathrm{~g} / \mathrm{cm}^{3}$ ), viscosity ( 33.0 to $65.4 \mathrm{~mm} / \mathrm{s}$ ), and cetane number (37 to 38 ) are different from rapeseed oils.

The biodiesels derived from different plant oils will have slightly different molecular structures such as carbon-chain lengths, hydrogen-carbon ratio and oxygen content due to the variation of the degree of unsaturation of the fatty acids in different sources. In Table 1, the density, viscosity and cetane number for rapeseed oil methyl esters (i.e. the biodiesel derived from rapeseed oils) can vary from 0.885 to $0.875 \mathrm{~g} / \mathrm{cm}^{3}$, 4.59 to $6.38 \mathrm{~mm}^{2} / \mathrm{s}$, and 53.0 to 54.5 , respectively; while the density, viscosity and cetane number for soybean oil methyl esters (i.e. biodiesel derived from soybean oils) can vary from 0.873 to $0.885 \mathrm{~g} / \mathrm{cm}^{3}, 4.05$ to $6.62 \mathrm{~mm}^{2} / \mathrm{s}$, and 51.0 to 51.3, respectively. The data in Table 1 show that the viscosities of plant oils are much higher compared with conventional diesel. Plant oils are denser, and have lower calorific values with lower cetane numbers compared with diesel. The transesterification of the plant oils to methyl esters generally resulted in a drastic decrease of the viscosity with a slight drop in density while increasing the calorific value and cetane number. Nevertheless, the densities and viscosities of the methyl esters are still slightly higher than diesel. Although the cetane numbers of most methyl esters are comparable with diesel, the calorific values of biodiesels are still much lower than that of diesel.

The differences in biodiesel properties would lead to differences in injection, combustion, performance and emission characteristics of the diesel engine. To further understand the characteristics of different biodiesels, this paper examines their effects on engine performances and emissions.

\section{Biodiesel Production}

Biodiesel, in general, involves conversion of the oil (long and branched chain triglyceride molecules) to its methyl esters. This transesterification process requires the use of methanol in a basic solution such as potassium or sodium hydroxide to produce the monoester and the glycerol as a by-product. The properties of these esters are similar to those of the petroleum diesel. However, the vegetable oil usually cannot be directly used in the transesterification step because of its high content of free fatty acids (FFA). Under alkaline conditions this treatment tends to produce soap that reduces the yield of the reaction, requires excessive utilization of alkali and a slower reaction time leading to the risk of an incomplete conversion. Therefore, pre-treatment with methanol under acidic conditions is necessary to reduce the amount of FFA by converting them to fatty acid methyl esters (FAME). A two-step process: acid-catalysed pre-treatment (Figure 1) and base-catalysed transesterification (Figure 2) is thus necessary.

\section{Characteristics of Biodiesels on Engine Performances}

Table 2 summarizes the specifications of some of the engines used in the investigations of the impact of biodiesels on engine performances. Even though the procedure for testing engine performances and emissions for different methyl esters is similar, the engines studied were not identical. The engines used had different power capacities and compression ratios involving both direct and indirect injection systems.

Figure 3 summarizes the average percentage change in power for different biodiesels after the engines were switched from diesel to run on the biodiesels. Most engines experienced a loss in power when operating on biodiesels. This can be attributed to the calorific value of biodiesel, which is generally lower than that of diesel due to the chemical composition and the differences in carbon, hydrogen, oxygen and sulfur content (Channiwala \& Parikh, 2002). Compared with conventional diesel, biodiesel generally has higher oxygen but lower sulfur contents and this correlates to a lower calorific value, which would lead to less power. The intensity of the change in power would ultimately depend on the engine type, injection system and design. In some 
engines the changes in power may not be significant as shown in Figure 3.

Lower calorific values also generally imply higher brake specific fuel consumption (BSFC) as higher fuel consumption rates are required at the same loading condition to attain the same power. Figure 4 shows the average percentage change in BSFC for different biodiesels after the engines were switched from diesel to biodiesels. Higher BSFCs are needed for the biodiesels. The density of biodiesel is slightly higher than diesel and this could also affect the BSFC. Fuel is delivered to the engine on a volumetric basis. For the same fuel volume, an increase in fuel density would imply a larger mass flow rate to the cylinders and this would increase the brake specific fuel consumption. The intensity of the change in BSFC would ultimately depend on the injection system as the distribution of fuel-air packets inside the spray may affect the required fuel per cycle.

Instead of using pure biodiesel, plant or animal oil methyl esters are often used as supplements to form diesel fuel blends at ratios of 10/90 and 20/80 (i.e. methyl ester to diesel ratio). Interestingly, the blend content can also influence the BSFC and power generated. Figure 5 shows the average percentage change in BSFC for different blends of biodiesels after the engines were switched from diesel to run on the blends. More diesel content in the blend usually leads to lower percentage change in BSFC. The percentage change in BSFC of biodiesel blends in Figure 5 is generally lower than that of the neat methyl esters shown in Figure 4.

Figures 3 and 4 compare the average percentage changes in power and BSFC for different biodiesels with respect to diesel. The instantaneous changes in power and BSFC would depend on the engine design, speed and loading conditions. Engines with higher compression ratios would result in higher temperatures and pressures during mixing of the burning gas in the cylinder. This promotes more complete combustion and affects the instantaneous percentage changes in power and BSFC. Engine speed would affect the mixing process with higher engine speed normally giving a better mixture. Higher engine speeds would also normally result in higher cylinder temperature and pressure. At higher engine speeds, and at higher temperatures, a better mixture would enhance the burning of the fuel. On the contrary lowering the engine speed would lower the cylinder temperature and this can lead to poorer vaporization and atomization. Figure 6 compares the changes in BSFCs with respect to diesel at different engine speeds and at full loads for some biodiesels.

\section{Characteristics of Biodiesels on Engine Emissions}

Biodiesel is an oxygenated fuel and the oxygen content facilitates the ignition. This improves the combustion process. The oxygen in biodiesel would also raise the bulk temperature during combustion. This is important as higher temperatures close to the stoichiometric conditions aids the formation of $\mathrm{NO}_{\mathrm{x}}$. At high temperatures, $\mathrm{N}_{2}$ and $\mathrm{O}_{2}$ would combine to form $\mathrm{NO}_{\mathrm{x}}$. Figure 7 shows the average percentage change in $\mathrm{NO}_{\mathrm{x}}$ for different biodiesels after the engines were switched from diesel to operate on the biodiesels. Most of the biodiesels emit more $\mathrm{NO}_{\mathrm{x}}$ than diesel although there are cases where the opposite occurs. The amount of $\mathrm{NO}_{\mathrm{x}}$ produced would depend on the nitrogen and oxygen content in the biodiesels as well as the combustion dynamics, which can be influenced by the adiabatic flame temperature, duration of high burning gas temperature, sprays characteristics and ignition delay. As such, the $\mathrm{NO}_{\mathrm{x}}$ concentration could vary with the engine speed and loading conditions. Studies have found that there is a correlation between the iodine number, which quantifies the number of double bonds, and the $\mathrm{NO}_{\mathrm{x}}$ emissions (Peterson et al., 2000; McCormick et al., 2001). As a rule of thumb, biodiesels with more saturated carbon bonds generally produce less $\mathrm{NO}_{\mathrm{x}}$ emissions. The iodine number increases with the level of unsaturation and is associated with the biodiesel's carbon-chain structure as well as fuel properties such as cetane number, density, bulk modulus and freezing point.

Similar to BSFC and power, blends of biodiesels can also alter the $\mathrm{NO}_{\mathrm{x}}$ emissions. Figure 8 shows the average percentage change in $\mathrm{NO}_{\mathrm{x}}$ for different blends with respect to conventional diesel. Most blends emit less $\mathrm{NO}_{\mathrm{x}}$ than diesel. B20 biodiesel (i.e. blend at ratios of 20/80) seems to produce less $\mathrm{NO}_{\mathrm{x}}$ emissions than $\mathrm{B} 10$ biodiesel. Comparing Figures 7 and 8, less $\mathrm{NO}_{\mathrm{x}}$ is emitted with blends than neat biodiesels.

$\mathrm{CO}$ is one of the consequences of incomplete fuel combustion. Figure 9 shows the average percentage change in $\mathrm{CO}$ for different biodiesels after the engines were switched from diesel to operate on the biodiesels. Less CO is generated with biodiesels than diesel. Concentration of oxygen during combustion would enhance the oxidation rate of $\mathrm{CO}$ and lead to less $\mathrm{CO}$ formation. This is a major advantage of oxygenated fuels like biodiesel. However, the intensity of the $\mathrm{CO}$ reduction can be affected by the engine loading and speed condition. At low speed, the lower burning gas temperature could hinder the conversion rate of $\mathrm{CO}$ to $\mathrm{CO}_{2}$ and more $\mathrm{CO}$ can be emitted. It should be noted that the carbon contents of different biodiesels are not the same and most biodiesels have less carbon content than diesel. This could also affect the percentage change in $\mathrm{CO}$ emissions.

Viscosity determines the liquid's ability to flow and signifies the mean droplet size associated with the atomization process. Larger droplets are usually formed with fuel of higher viscosity. The droplet size becomes 
important during injection and combustion. Larger droplets prevent adequate breakdown of the fuel during the injection process and their evaporation is more difficult during the combustion stage. These factors can lead to inefficient combustion and produce more black smoke, which is formed primarily due to the incomplete burning of the hydrocarbon and the carbon reaction in the fuel.

Figure 10 shows the average percentage change in smoke opacity for different biodiesels after the engines were switched from diesel to operate on the alternative fuels. Almost all the biodiesels show a decrease in the percentage change in smoke opacity compared with conventional diesel. Although biodiesel has slightly higher viscosity than diesel, its lower stoichiometric air/fuel ratio compared with neat diesel can lead to less black particulate emissions. The stoichiometric air/fuel ratio in biodiesel is lowered mainly by the bound oxygen and the oxygen enriched air. The intensity of the smoke emission reduction with biodiesel could also depend on the fatty acid compositions and fuel molecular structures. Higher content of shorter carbon-chains generally have better ignition quality and less smoke emissions (Auld et al., 1982). However, biodiesel may contain different compositions by weight of constituents with different molecular structures. As a result, the constituents can burn and evaporate at different rates. Constituents that continue to burn in the late combustion stage would contribute to the exhaust gas temperature, while un-burned constituents can form soot. It should be noted that although shorter carbon-chains can improve ignition leading to complete combustion at lower temperatures, the consequence would imply that higher brake specific fuel consumption will be needed to support the process. Furthermore, the combustion characteristics of biodiesels are affected by the cylinder gas pressure, heat release rate and ignition delay and these variables can be dependent on loading and speed conditions. For short combustion processes at high speeds, the amount of total hydrocarbon emissions could be different from that at low speeds.

Figure 11 shows the average percentage change in exhaust gas temperature for different biodiesels after the engines were switched from diesel to operate on the biodiesels. The cetane number refers to the ease with which the fuel can ignite. A high cetane number ensures good cold start and is associated with shorter ignition delay and shorter premixed combustion, resulting in faster burning rate without late combustion in the expansion stroke. These factors would lead to lower exhaust temperatures. The slightly higher cetane number of most biodiesels compared with diesel would explain the general trend shown in Figure 11. Besides higher combustion efficiency, the lower energy content of most biodiesels compared with diesel could also lead to lower exhaust gas temperatures. Hess et al. (2005) found that the ignition timing of biodiesel may be advanced due to its higher isentropic bulk modulus. Exhaust gas temperature can be affected by the changes in ignition delay, with longer ignition delay often resulting in a delayed combustion and higher exhaust gas temperature.

The performances of the various biodiesels indicated that $\mathrm{NO}_{\mathrm{x}}$ emissions can be higher, while $\mathrm{CO}$ and smoke emissions are generally lower than conventional diesel. Most engines experienced power losses with higher BSFC when operating on biodiesels. The intensities of these changes are mainly influenced by the complex interaction between the combustion dynamics and the fuel thermo-physical properties. The combustion efficiency would depend on the engine design, injection system, composition of the air-fuel ratio, as well as the loading and speed conditions. The physicochemical properties of biodiesels may vary due to the differences in feedstock, conversion processes and separation efficiencies. Factors such as chemical compositions, carbon-chain lengths, degree of saturation and impurities will influence the performances of the biodiesels in diesel engines.

\section{Future Perspectives}

There are tremendous opportunities for improving the physical characteristics of biodiesel. Vegetable oils generally have bigger and heavier molecular weights than biodiesels and neat diesels due to heavier triglyceride molecules and more long-chain fatty acids. The transesterification process reduces the molecular weight. Heavier molecules can contribute to the production of more soot as longer hydrocarbon chains have the potential to release a larger quantity of black particulate matter. Feedstock with different proportions of saturated, mono-unsaturated, and polyunsaturated fatty acids can produce different qualities of biodiesels with slightly different properties. Saturated fatty acids usually have longer chains and their chemical bonds can lower the combustion temperature and $\mathrm{NO}_{\mathrm{x}}$ emissions (Lee et al., 1998). On the other hand, unsaturated fatty acids containing one or more reactive double bonds can significantly increase the tendency to undergo oxidation degradation and increase the $\mathrm{NO}_{\mathrm{x}}$ emissions (Knothe et al., 2003). Table 3 shows the typical weight percent of fatty acids in some common oil feedstock. Additives, catalysts and production strategies can alter the characteristics of the biodiesel. The key to improving the quality of biodiesel may well lie in finding suitable ingredients with the right proportions of fatty acids as well as developing optimal catalysts and processes to transform the feedstock into biodiesels with desired properties. 
There are many important considerations in the search for suitable ingredients and processes to produce quality biodiesels. Recent developments have focused on the search for and development of cheap land-based energy crops with high oil contents quantified mainly by cost per kilograms of oil per hectare. However, by harvesting agricultural land for the feedstock, many developments had ignored the competition created between the use of resources for food production and biodiesel production. The generation of biodiesels from edible crops tends to intensify food prices as well as shortages. In some regions, abstraction of energy from "power-plants" has led to land-grabbing, deforestation and animosity between inhabitants and those that grow "energy-crops". It was estimated that such deforestation and agricultural activities accounted for $75 \%$ of Brazil's greenhouse gas emission. To overcome these problems, it is vital that cultivation of suitable cost-effective feedstock should not impact adversely on feeding the growing global population. In this respect the search for non-edible, cheap, and stable raw oil sources can be critical for the future development of the biodiesel industry. One potential solution is algae, which can have a higher oil yield than land-based oleaginous plants (Aresta et al., 2005). Ecology and environment are other factors. It is essential that genetic modification of suitable feedstock or the introduction of foreign crops for biodiesel production should not disturb the regional ecological system. Furthermore, the generation of biodiesel should not in any way cause any environmental damage. From this aspect, the recycling of waste oils to biodiesels should be encouraged. Advanced processing technologies and more efficient production methods would be needed to support such initiatives to further lower the cost and improve the quality of biodiesels from waste oil.

It is vital that the fuel used should match the engine. The fuel characteristics would depend on engine type, size, design and operating conditions. Using fuels with better characteristics do not necessarily improve engine performance. On the other hand, using fuels with characteristics below the minimum engine requirements can cause rough engine operation. Biodiesels from different feedstock can vary in composition and purity and may need different engine settings for optimum performance. To enhance the performances of biodiesel-fuelled engines, improving the engine design is essential. Better knowledge of the combustion process, compression ratios, spark timing, and lean operational limits in engines with biodiesels will be needed for improving the engine designs. For example, fuel density and viscosity can influence the atomization and affect the air-fuel mixing rate. Low viscosity fuel is easier to inject, atomize and mix with air. As such the viscosity will affect the spray angle. The higher bulk modulus of biodiesels can lead to advanced injection timing. Tat et al. (2003) found that the isentropic bulk modulus of unsaturated fatty acid methyl ester is higher than that of saturated fatty acid methyl ester. Injection pressure can also change the effect of biodiesel on engine performance and emissions (Celikten et al., 2010). These issues indicated that advanced fuel injection systems may be needed for biodiesels. Currently, improvements to diesel engines include not only enhanced fuel injection control strategies (e.g. multi-stage injection system), but also exhaust gas recirculation devices.

Besides engine improvement, the long term storage and usage of biodiesels also has to be resolved. Biodiesels are biodegradable and the oxidation stability can affect their properties if the fuels were stored for a long period of time (Monyem et al., 2001). Oxidation as the biodiesel ages can lead to high acid numbers, high viscosity, polymerization, and the formation of gums and sediments. Degradation of the fuel with time will lead to the point where the biodiesel is out of specification and should not be used. Oxidation resistance is affected by the fatty acid composition and higher iodine number often indicates lower oxidation stability. Although biodiesel with high oxidation stability can be stored longer, the fuel is generally not stored for long periods of time. The recommended storage life for pure biodiesel is about six months. Based on this shelf life, biodiesel production rates and levels must be optimized with respect to the distribution logistics and inventory to meet the just-in-time demands of the consumers. The presence of bacteria and other contaminants can also affect the fuel stability and biological contamination can be a problem during storage. Aerobic fungus, bacteria, and yeast hydrocarbon utilizing microorganisms usually grow at the fuel-water interface and can cause corrosion. Long term usage of oil with high saturated fatty acid content will generally cause a high cold filter plugging point and reduce fluidity (Knothe, 2005). Their long-term utilization may lead to injector choking, more carbon deposits, piston oil-ring sticking and gelling of engine lubricating oil. Furthermore, trace metals in biofuels can cause unwanted problems and long term operation of biodiesel could corrode and degrade engine components due to the presence of oxygen and trace metals (Pillay et al., 2012).

\section{Conclusion}

The review of biodiesels of different origins on engine performances and emissions indicated that this form of alternative fuel can be an attractive renewable alternative energy source for diesel engines. Physical and chemical properties of biodiesels can have significant effects on the combustion process, which will impact on the engine performance and emissions. For better performance and emission, the engines should match the 
biodiesel characteristics. The search for cost-effective feedstock and processes to produce quality biodiesels must not only consider economical factors, but also focus on long term ecological and environmental issues. Besides finding suitable feedstock, developing optimal conversion processes, and improving the engine designs, the future development of biodiesels may also depend on the resolution of long term usage and storage problems.

\section{References}

Abdul Aziz A., Said M. F., \& Awang M. A. (2005). Performance of palm oil-based biodiesel fuels in a single cylinder direct injection engine. Palm Oil Develop, 42, 15-27.

Aresta M., Dibenedetto A., Carone M., Colonna T., \& Fragale C. (2005). Production of biodiesel from macroalgae by supercritical $\mathrm{CO}_{2}$ extraction and thermochemical liquefaction. Environmental Chemistry Letters, 3 (3), 136-139. http://dx.doi.org/10.1007/s10311-005-0020-3

Auld D. L., Bettis B. L., \& Peterson C. L. (1982). Production and fuel characteristics of vegetable oilseed crops in the Pacific Northwest. Proceedings of the International Conference on Plant and Vegetable Oils Fuel, St. Joseph, MI: ASAE.

Aydin H., \& Bayindir H. (2010). Performance and emission analysis of cottonseed oil methyl ester in a diesel engine. Renewable Energy, 35, 588-592. http://dx.doi.org/10.1016/j.renene.2009.08.009

Buyukkaya E. (2010). Effects of biodiesel on a DI diesel engine performance, emission and combustion characteristics. Fuel, http://dx.doi.org/10.1016/j.fuel.2010.05.034

Celikten I., Koca A., \& Arslan M. A. (2010). Comparison of performance and emissions of diesel fuel, rapeseed and soybean oil methyl esters injected at different pressures. Renewable Energy, 35, 814-820. http://dx.doi.org/10.1016/j.renene.2009.08.032

Channiwala S. A., \& Parikh, P. P. (2002). A unified correlation for estimating HHV of solid, liquid and gaseous fuels. Fuel, 81, (8), 1051-1063. http://dx.doi.org/10.1016/S0016-2361(01)00131-4

Goering C. E, Schwab A.W., Daugherty M. J., Pryde E. H., \& Heakin A. J. (1982). Fuel properties of eleven vegetable oils. Transactions of the ASAE, 25 (6), 1472-1483.

Hess M. A., Haas M. J., Foglia T. A., \& Marmer W. N. (2005). The effect of antioxidant addition on $\mathrm{NO}_{\mathrm{x}}$ emissions from biodiesel. Energy and Fuels, 19 (4), 1749-1754. http://dx.doi.org/10.1021/ef049682s

Hossain A. K., \& Davies P. A. (2010). Plant oils as fuels for compression ignition engines: a technical review and life-cycle analysis. Renewable Energy, 35, 1-13. http://dx.doi.org/10.1016/j.renene.2009.05.009

Ilkilic C., \& Yucesu H. S. (2005). Investigation of the effect of sunflower oil methyl ester on the performance of a diesel engine. Energy Sources, 27, 1225-1234. http://dx.doi.org/10.1080/009083190519311

Kalam M. A., \& Masjuki H. (2002). Biodiesel from palm oil - an analysis of its properties and potential. Biomass and Bioenergy, 23, 471-479. http://dx.doi.org/10.1016/S0961-9534(02)00085-5

Knothe G. (2005). Dependence of biodiesel fuel properties on the structure of fatty acid alkyl esters. Fuel Processing Technology, 86, (10), 1059-1070. http://dx.doi.org/10.1016/j.fuproc.2004.11.002

Knothe G., Matheaus A. C., \& Ryan T. W. (2003). Cetane number of branched and straight-chain fatty acid esters determined in an ignition quality tester. Fuel, 82, 971-975. http://dx.doi.org/10.1016/S0016-2361(02)00382-4

Lee R., Hobbs C. H., \& Pedley J. F. (1998). Fuel quality impact on heavy-duty diesel emissions: a literature review. SAE Technical paper series 982649.

Lin B-F., Huang J-H., \& Huang D-Y. (2009). Experimental study of the effects of vegetable oil methyl ester on DI diesel engine performance characteristics and pollutant emissions. Fuel, 88, 1779-1785. http://dx.doi.org/10.1016/j.fuel.2009.04.006

Lin C-Y., \& Li R-J. (2009). Engine performance and emission characteristics of marine fish-oil biodiesel produced from the discarded parts of marine fish. Fuel Processing Technology, 90, 883-888. http://dx.doi.org/10.1016/j.fuproc.2009.04.009

Masjuki H., Abdulmuin M. Z., \& Sii H. S. (1997). Indirect injection diesel engine operation on palm oil methyl esters and its emulsions. Proceedings of the Institution of Mechanical Engineers, Part D, 211, 291-299.

McCormick R. L., Graboski M. S., Alleman T. L., Herring A. M., \& Shaine T. K. (2001). Impact of biodiesel source material and chemical structure on emissions of criteria pollutants from a heavy-duty engine. Environmental Science \& Technology, 35, (9), 1742-1747. http://dx.doi.org/10.1021/es001636t 
Monyem A., Van Gerpen J. H., \& Canakci M. (2001). The effect of timing and oxidation on emissions from biodiesel-fueled engines. Transaction of the ASAE, 44, (1), 35-42.

Ozsezen A. N., \& Canakci M. (2010). Determination of performance and combustion characteristics of a diesel engine fueled with canola and waste palm oil methyl esters. Energy Conversion and Management, http://dx.doi.org/10.1016/j.enconman.2010.06.049

Peterson C. L., Taberski J. S., Thompson J. C., \& Chase C. L. (2000). The effect of biodiesel feedstock on regulated emissions in chassis dynamometer tests of a pickup truck. Transactions of the ASAE, 43 (6), 1371-1381.

Pillay A. E., Elkadi M., Fok S. C., Stephen S., Manuel J., Khan M. Z., \& Unnithan S. (2012). A comparison of trace metal profiles of neem biodiesel and commercial biofuels using high performance ICP-MS. Fuel, (in press). http://dx.doi.org/10.1016/j.fuel.2012.02.040

Qi D. H., Geng L. M., Chen H, Bian Y. Z. H., Liu J., \& Ren X. C. H. (2009). Combustion and performance evaluation of a diesel engine fueled with biodiesel produced from soybean crude oil. Renewable Energy, 34, 2706-2713. http://dx.doi.org/10.1016/j.renene.2009.05.004

Raheman H., \& Ghadge S. V. (2007). Performance of compression ignition engine with mahua (Madhuca indica) biodiesel. Fuel, 86, 2568-2573. http://dx.doi.org/10.1016/j.fuel.2007.02.019

Rakopoulos C. D., Antonopoulos K. A., Rakopoulos D. C,. Hountalas D. T., \& Giakoumis E. G. (2006). Comparative performance and emissions study of a direct injection diesel engine using blends of diesel fuel with vegetable oils or bio-diesels of various origins. Energy Conversion and Management, 47, 3272-3287. http://dx.doi.org/10.1016/j.enconman.2006.01.006

Rodjanakid K., \& Charoenphonphanich C. (2004). Performance of an engine using biodiesel from refined palm oil stearin and biodiesel from crude coconut oil. Proceedings of the Joint International Conference on Sustainable Energy and Environment, Hua Hin, Thailand, 1-3 December.

Sayin C. (2010). Engine performance and exhaust gas emissions of methanol and ethanol-diesel blends. Fuel, http://dx.doi.org/10.1016/j.fuel.2010.02.017

Singh S. P., \& Singh D. (2010). Biodiesel production through the use of different sources and characterization of oils and their esters as the substitute of diesel: a review. Renewable and Sustainable Energy Reviews, 14, 200-216. http://dx.doi.org/10.1016/j.rser.2009.07.017

Tat M. E., \& Van Gerpen J. H. (2003). Measurement of biodiesel speed of sound and its impact on injection timing. NREL/SR-510-31462.

Usta N. (2005). An experimental study on performance and exhaust emissions of a diesel engine fuelled with tobacco seed oil methyl ester. Energy Conversion and Management, 46, 2373-2386. http://dx.doi.org/10.1016/j.enconman.2004.12.002

Wu F., Wang J., Chen W., \& Shuai S. (2009). A study on the emission performance of a diesel engine fueled with five typical methyl ester biodiesels. Atmospheric Environment, 43, 1481-1485. http://dx.doi.org/10.1016/j.atmosenv.2008.12.007 
Table 1. Comparison of some biodiesel fuel properties

\begin{tabular}{|c|c|c|c|c|}
\hline Fuel type & $\begin{array}{l}\text { Density } \\
\left(\mathrm{gcm}^{-3}\right)\end{array}$ & $\begin{array}{l}\text { Viscosity } \\
\left(\mathrm{mm}^{2} \mathrm{~s}^{-1}\right)\end{array}$ & $\begin{array}{l}\text { Calorific value } \\
\left(\mathrm{MJkg}^{-1}\right)\end{array}$ & $\begin{array}{l}\text { Cetane } \\
\text { number }\end{array}$ \\
\hline Diesel & 0.837 & 3.25 & 44.4 & 51.2 \\
\hline $\begin{array}{l}\text { Rapeseed oil methyl ester } \\
\text { (RSOME) (Lin et al., 2009) }\end{array}$ & $0.885\left(15^{\circ} \mathrm{C}\right)$ & $4.59\left(40^{\circ} \mathrm{C}\right)$ & 39.9 & 54.5 \\
\hline $\begin{array}{c}\text { (RSOME) } \\
\text { (Wu et al, 2009) }\end{array}$ & 0.873 & $6.38\left(20^{\circ} \mathrm{C}\right)$ & 39.8 & 53.0 \\
\hline $\begin{array}{c}\text { (RSOME) } \\
\text { (Rakopoulos et al., 2006) }\end{array}$ & $0.885\left(15^{\circ} \mathrm{C}\right)$ & $4.70\left(40^{\circ} \mathrm{C}\right)$ & 37.3 & 53.0 \\
\hline $\begin{array}{c}\text { Rapeseed oil (RSO) } \\
\text { (Buyukkaya, 2010) }\end{array}$ & $0.920\left(15^{\circ} \mathrm{C}\right)$ & $35.0\left(40^{\circ} \mathrm{C}\right)$ & 37.1 & 39.0 \\
\hline $\begin{array}{c}\text { (RSO) } \\
\text { (Celikten et al., 2010) }\end{array}$ & 0.872 & $11.0\left(27^{\circ} \mathrm{C}\right)$ & 39.7 & 37.6 \\
\hline $\begin{array}{c}\text { (RSO) } \\
\text { (Hossain et al., 2010) }\end{array}$ & 0.914 & $39.2\left(27^{\circ} \mathrm{C}\right)$ & 37.6 & 37.6 \\
\hline $\begin{array}{l}\text { Canola oil methyl ester (CaOME) } \\
\text { (Ozsezen et al., 2010) }\end{array}$ & $0.883\left(15^{\circ} \mathrm{C}\right)$ & $4.49\left(40^{\circ} \mathrm{C}\right)$ & 39.0 & - \\
\hline $\begin{array}{c}\text { Corn oil methyl ester (COME) } \\
\text { (Lin et al., 2009) }\end{array}$ & $0.885\left(15^{\circ} \mathrm{C}\right)$ & $4.36\left(40^{\circ} \mathrm{C}\right)$ & 39.8 & 55.4 \\
\hline $\begin{array}{c}\text { Corn oil (CO) } \\
\text { (Rakopoulos et al., 2006) }\end{array}$ & $0.915\left(15^{\circ} \mathrm{C}\right)$ & $35.0\left(40^{\circ} \mathrm{C}\right)$ & 36.3 & 38.0 \\
\hline $\begin{array}{c}(\mathrm{CO}) \\
\text { (Hossain et al., 2010) }\end{array}$ & 0.915 & $46.3\left(40^{\circ} \mathrm{C}\right)$ & 37.8 & 37.6 \\
\hline $\begin{array}{c}\text { (CO) } \\
\text { (Singh et al., 2010) }\end{array}$ & 0.909 & $34.9\left(38^{\circ} \mathrm{C}\right)$ & 39.5 & 37.6 \\
\hline $\begin{array}{l}\text { Soybean oil methyl ester (SBOME) } \\
\text { (Lin et al., 2009) }\end{array}$ & $0.885\left(15^{\circ} \mathrm{C}\right)$ & $4.05\left(40^{\circ} \mathrm{C}\right)$ & 39.7 & 51.3 \\
\hline $\begin{array}{c}\text { (SBOME) } \\
\text { (Wu et al., 2009) }\end{array}$ & 0.873 & $6.62\left(20^{\circ} \mathrm{C}\right)$ & 39.9 & 51.0 \\
\hline $\begin{array}{c}\text { (SBOME) } \\
\text { (Rakopoulos et al., 2006) }\end{array}$ & $0.885\left(15^{\circ} \mathrm{C}\right)$ & $4.10\left(40^{\circ} \mathrm{C}\right)$ & 37.3 & 51.0 \\
\hline $\begin{array}{c}\text { (SBOME) } \\
\text { (Qi et al., 2009) }\end{array}$ & $0.870\left(20^{\circ} \mathrm{C}\right)$ & $5.20\left(40^{\circ} \mathrm{C}\right)$ & 38.8 & 47.0 \\
\hline $\begin{array}{l}\text { Soybean oil (SBO) } \\
\text { (Celikten et al., 2010) }\end{array}$ & 0.914 & $39.5\left(27^{\circ} \mathrm{C}\right)$ & 37.6 & 37.0 \\
\hline $\begin{array}{c}\text { (SBO) } \\
\text { (Rakopoulos et al., 2006) }\end{array}$ & $0.925\left(15^{\circ} \mathrm{C}\right)$ & $33.0\left(40^{\circ} \mathrm{C}\right)$ & 37.0 & 38.0 \\
\hline $\begin{array}{c}\text { (SBO) } \\
\text { (Hossain et al., 2010) }\end{array}$ & 0.914 & $65.4\left(40^{\circ} \mathrm{C}\right)$ & 39.6 & 38.0 \\
\hline $\begin{array}{l}\text { Coconut oil ethyl ester (CNOES) } \\
\text { (Rodjanakid et al., 2004) }\end{array}$ & $0.920\left(15^{\circ} \mathrm{C}\right)$ & $23.7\left(40^{\circ} \mathrm{C}\right)$ & 37.1 & - \\
\hline $\begin{array}{c}\text { Coconut oil (CCO) } \\
\text { (Hossain et al., 2010) }\end{array}$ & 0.915 & $31.6\left(27^{\circ} \mathrm{C}\right)$ & 35.8 & - \\
\hline $\begin{array}{l}\text { Palm oil methyl ester (POME) } \\
\text { (Masjuki et al., 1997) }\end{array}$ & 0.875 & $4.71\left(40^{\circ} \mathrm{C}\right)$ & 41.3 & $50-52$ \\
\hline $\begin{array}{c}\text { (POME) } \\
\text { (Lin et al., 2009) }\end{array}$ & $0.878\left(15^{\circ} \mathrm{C}\right)$ & $4.69\left(40^{\circ} \mathrm{C}\right)$ & 39.9 & 62.0 \\
\hline $\begin{array}{c}\text { (POME) } \\
\text { (Wu et al., 2009) }\end{array}$ & 0.878 & $7.10\left(20^{\circ} \mathrm{C}\right)$ & 40.1 & 64.0 \\
\hline $\begin{array}{l}\text { Palm oil methyl ester (POME) } \\
\text { (Rakopoulos et al., 2006) }\end{array}$ & $0.870\left(15^{\circ} \mathrm{C}\right)$ & $4.50\left(40^{\circ} \mathrm{C}\right)$ & 37.2 & 50.0 \\
\hline $\begin{array}{l}\text { Palm kernel oil methyl ester (PKOME) } \\
\text { (Lin et al., 2009) }\end{array}$ & $0.876\left(15^{\circ} \mathrm{C}\right)$ & $3.24\left(40^{\circ} \mathrm{C}\right)$ & 38.5 & 62.1 \\
\hline $\begin{array}{l}\text { Refined palm oil stearin (RPOS) } \\
\text { (Rodjanakid et al., 2004) }\end{array}$ & $0.864\left(15^{\circ} \mathrm{C}\right)$ & $6.32\left(40^{\circ} \mathrm{C}\right)$ & 40.4 & - \\
\hline $\begin{array}{c}\text { Palm oil (PO) } \\
\text { (Hossain et al., 2010) }\end{array}$ & 0.918 & $39.6\left(38^{\circ} \mathrm{C}\right)$ & 36.5 & 42.0 \\
\hline
\end{tabular}


Table 1. Comparison of some biodiesel fuel properties (continued)

\begin{tabular}{|c|c|c|c|c|}
\hline Fuel type & $\begin{array}{l}\text { Density } \\
\left(\mathrm{gcm}^{-3}\right)\end{array}$ & $\begin{array}{l}\text { Viscosity } \\
\left(\mathrm{mm}^{2} \mathrm{~s}^{-1}\right)\end{array}$ & $\begin{array}{l}\text { Calorific value } \\
\left(\mathrm{MJkg}^{-1}\right)\end{array}$ & $\begin{array}{l}\text { Cetane } \\
\text { number }\end{array}$ \\
\hline $\begin{array}{l}\text { Peanut oil methyl ester (PNOME) } \\
\text { (Lin et al., 2009) }\end{array}$ & $0.886\left(15^{\circ} \mathrm{C}\right)$ & $5.25\left(40^{\circ} \mathrm{C}\right)$ & 39.7 & 54.0 \\
\hline $\begin{array}{c}\text { (PNOME) } \\
\text { (Singh et al., 2010) }\end{array}$ & 0.883 & $4.90\left(37.8^{\circ} \mathrm{C}\right)$ & 33.6 & 54.0 \\
\hline $\begin{array}{c}\text { Peanut oil (PNO) } \\
\text { (Hossain et al., 2010) }\end{array}$ & 0.903 & $39.6\left(38^{\circ} \mathrm{C}\right)$ & 39.8 & 41.8 \\
\hline $\begin{array}{c}\text { Sunflower oil methyl ester (SFOME) } \\
\text { (Ilkilic et al., 2005) }\end{array}$ & $0.880\left(26^{\circ} \mathrm{C}\right)$ & $4.50\left(26^{\circ} \mathrm{C}\right)$ & 39.3 & 49.0 \\
\hline $\begin{array}{c}\text { (SFOME) } \\
\text { (Lin et al., 2009) } \\
\end{array}$ & $0.886\left(15^{\circ} \mathrm{C}\right)$ & $4.38\left(40^{\circ} \mathrm{C}\right)$ & 39.9 & 51.6 \\
\hline $\begin{array}{c}\text { (SFOME) } \\
\text { (Rakopoulos et al., 2006) }\end{array}$ & $0.880\left(15^{\circ} \mathrm{C}\right)$ & $4.40\left(40^{\circ} \mathrm{C}\right)$ & 37.5 & 50.0 \\
\hline $\begin{array}{c}\text { Sunflower oil (SFO) } \\
\text { (Rakopoulos et al., 2006) }\end{array}$ & $0.920\left(15^{\circ} \mathrm{C}\right)$ & $34.0\left(40^{\circ} \mathrm{C}\right)$ & 36.5 & 37.0 \\
\hline $\begin{array}{c}\text { (SFO) } \\
\text { (Hossain et al., 2010) }\end{array}$ & 0.918 & $58.5\left(27^{\circ} \mathrm{C}\right)$ & 39.5 & 37.1 \\
\hline $\begin{array}{c}\text { (SFO) } \\
\text { (Singh et al., 2010) }\end{array}$ & 0.916 & $33.9\left(38^{\circ} \mathrm{C}\right)$ & 39.6 & 37.1 \\
\hline $\begin{array}{l}\text { Mahua oil methyl ester (MOME) } \\
\text { (Raheman et al., 2007) }\end{array}$ & $0.880\left(15^{\circ} \mathrm{C}\right)$ & $3.98\left(40^{\circ} \mathrm{C}\right)$ & 36.8 & - \\
\hline $\begin{array}{c}\text { Mahua oil (MO) } \\
\text { (Hossain et al., 2010) }\end{array}$ & 0.900 & $37.2\left(27^{\circ} \mathrm{C}\right)$ & 38.8 & - \\
\hline $\begin{array}{c}\text { Olive kernel oil (OlivO) } \\
\text { (Rakopoulos et al., 2006) }\end{array}$ & $0.925\left(15^{\circ} \mathrm{C}\right)$ & $32.0\left(40^{\circ} \mathrm{C}\right)$ & 37.0 & 39.0 \\
\hline $\begin{array}{l}\text { Cottonseed oil methyl ester (CSOME) } \\
\text { (Aydin et al., 2010) }\end{array}$ & $0.874\left(15^{\circ} \mathrm{C}\right)$ & $4.34\left(40^{\circ} \mathrm{C}\right)$ & 41.2 & 54.0 \\
\hline $\begin{array}{c}\text { (CSOME) } \\
\text { (Wu et al., 2009) }\end{array}$ & 0.880 & $6.38\left(20^{\circ} \mathrm{C}\right)$ & 39.7 & 54.0 \\
\hline $\begin{array}{c}\text { (CSOME) } \\
\text { (Rakopoulos et al., 2006) }\end{array}$ & $0.885\left(15^{\circ} \mathrm{C}\right)$ & $4.00\left(40^{\circ} \mathrm{C}\right)$ & 37.5 & 52.0 \\
\hline $\begin{array}{c}\text { Cottonseed oil (CSO) } \\
\text { (Rakopoulos et al., 2006) }\end{array}$ & $0.910\left(15^{\circ} \mathrm{C}\right)$ & $34.0\left(40^{\circ} \mathrm{C}\right)$ & 36.8 & 38.0 \\
\hline $\begin{array}{c}\text { (CSO) } \\
\text { (Hossain et al., 2010) }\end{array}$ & 0.912 & $0.100\left(27^{\circ} \mathrm{C}\right)$ & 39.6 & 48.1 \\
\hline $\begin{array}{c}\text { (CSO) } \\
(\text { Singh et al., 2010) }\end{array}$ & 0.915 & $33.5\left(38^{\circ} \mathrm{C}\right)$ & 39.5 & 41.8 \\
\hline $\begin{array}{l}\text { Tobacco seed methyl ester (TSOME) } \\
\text { (Usta, 2005) }\end{array}$ & $0.887\left(15^{\circ} \mathrm{C}\right)$ & $3.98\left(40^{\circ} \mathrm{C}\right)$ & 39.8 & 51.0 \\
\hline $\begin{array}{l}\text { Marine fish oil methyl ester (MFOME) } \\
\text { (Lin \& Li, 2009) }\end{array}$ & 0.860 & $7.20\left(\right.$ at $\left.40^{\circ} \mathrm{C}\right)$ & 41.4 & 50.9 \\
\hline $\begin{array}{l}\text { Waste fried oil methyl ester (WFOME) } \\
\text { (Lin et al. 2009) }\end{array}$ & $0.884\left(15^{\circ} \mathrm{C}\right)$ & $4.86\left(40^{\circ} \mathrm{C}\right)$ & 39.7 & 55.0 \\
\hline $\begin{array}{l}\text { Waste cooking oil methyl ester (WCOME) } \\
\text { (Wu et al., 2009) }\end{array}$ & 0.870 & $6.89\left(20^{\circ} \mathrm{C}\right)$ & 40.1 & 56.0 \\
\hline $\begin{array}{l}\text { Waste fried (palm) oil methyl ester } \\
\text { (WFOME) (Ozsezen et al., 2010) }\end{array}$ & $0.875\left(15^{\circ} \mathrm{C}\right)$ & $4.40\left(40^{\circ} \mathrm{C}\right)$ & 38.7 & 60.4 \\
\hline $\begin{array}{l}\text { Waste cooking oil biodiesel (WCOB) } \\
\text { (Lin \& Li, 2009) }\end{array}$ & 0.870 & $4.70\left(40^{\circ} \mathrm{C}\right)$ & 40.1 & 48.1 \\
\hline $\begin{array}{c}\text { Methanol } \\
(\text { Sayin, 2010) }\end{array}$ & $0.790\left(20^{\circ} \mathrm{C}\right)$ & $\begin{array}{l}75.0 \times 10-6 \\
\left(25^{\circ} \mathrm{C}\right)\end{array}$ & 1.1 & 4.0 \\
\hline $\begin{array}{c}\text { Ethanol } \\
\text { (Sayin, 2010) }\end{array}$ & $0.780\left(20^{\circ} \mathrm{C}\right)$ & $\begin{array}{l}151 \times 10-4 \\
\left(25^{\circ} \mathrm{C}\right)\end{array}$ & 0.92 & 6.0 \\
\hline
\end{tabular}


Table 2. Comparison of some diesel engines used in the biodiesel investigations

\begin{tabular}{|c|c|c|c|c|c|}
\hline Fuel type & $\begin{array}{l}\text { Engine used } \\
\text { (model) }\end{array}$ & $\begin{array}{l}\text { Cylinder number } \\
\text { (Displacement) }\end{array}$ & $\mathrm{CR}^{1}$ & $\begin{array}{l}\text { Max. } \\
\text { power } \\
(\mathrm{kW})\end{array}$ & $\begin{array}{l}\text { Max. } \\
\text { speed } \\
(\mathrm{rpm})\end{array}$ \\
\hline $\begin{array}{c}\text { RSO } \\
\text { (Buyukkaya, 2010) }\end{array}$ & $\begin{array}{c}\text { MAN - } \\
\text { (direct injection) }\end{array}$ & $\begin{array}{l}6 \text { cylinders } \\
(12829 \mathrm{cc})\end{array}$ & $17: 1$ & 164 & 2100 \\
\hline $\begin{array}{c}\text { CSOME } \\
\text { (Aydin et al., 2010) }\end{array}$ & $\begin{array}{l}\text { Rainbow - 186 Diesel: } \\
\text { (direct injection) }\end{array}$ & $\begin{array}{l}1 \text { cylinder } \\
(406 \mathrm{cc})\end{array}$ & $18: 1$ & 7.46 & 3600 \\
\hline $\begin{array}{c}\text { SFOME } \\
\text { (Ilkilic et al., 2005) }\end{array}$ & $\begin{array}{l}\text { Lombardini- } \\
\text { 6LD400: } \\
\text { direct injection }\end{array}$ & $\begin{array}{l}1 \text { cylinder } \\
(395 \mathrm{cc})\end{array}$ & $18: 1$ & 6.25 & 3600 \\
\hline $\begin{array}{c}\text { RPOS, CNOES } \\
\text { (Rodjanakid et al., 2004) }\end{array}$ & $\begin{array}{l}\text { Yanmar - TF85LM: } \\
\text { (indirect injection) }\end{array}$ & $\begin{array}{l}1 \text { cylinder } \\
(493 \mathrm{cc})\end{array}$ & $22.4: 1$ & 6.34 & 2200 \\
\hline $\begin{array}{c}\text { POME } \\
\text { (Kalam et al., 2002) }\end{array}$ & $\begin{array}{c}\text { Isuzu - 4FB1: } \\
\text { (indirect injection) }\end{array}$ & $\begin{array}{l}4 \text { cylinders } \\
(1817 \mathrm{cc})\end{array}$ & $21: 1$ & 39.0 & 5000 \\
\hline $\begin{array}{c}\text { TSOME } \\
\text { (Usta, 2005) }\end{array}$ & $\begin{array}{l}\text { Ford XLD418T } \\
\text { (indirect injection) }\end{array}$ & $\begin{array}{l}4 \text { cylinders } \\
(1753.4)\end{array}$ & $21.5: 1$ & 55.0 & 4500 \\
\hline $\begin{array}{c}\text { SBOME } \\
\text { (Qi et al., 2009) }\end{array}$ & (direct injection) & $\begin{array}{l}1 \text { cylinder } \\
(996 \mathrm{cc})\end{array}$ & $16.5: 1$ & 11.0 & 2000 \\
\hline $\begin{array}{c}\text { MOME } \\
\text { (Raheman et al., 2007) }\end{array}$ & $\begin{array}{c}\text { Ricardo E6 } \\
\text { (compression ignition) }\end{array}$ & 1 cylinder & $18: 1$ & 9.0 & 1500 \\
\hline $\begin{array}{c}\text { MFOME, WCOB } \\
\text { (Lin \& Li, 2009) }\end{array}$ & (direct injection) & $\begin{array}{l}4 \text { cylinders } \\
(3856 \mathrm{cc})\end{array}$ & - & - & - \\
\hline $\begin{array}{l}\text { CSOME, SBOME, SFOME, } \\
\text { RSOME, POME, CSO, } \\
\text { SBO, SFO, CO, OlivO } \\
\text { (Rakopoulos et al., 2006) }\end{array}$ & $\begin{array}{l}\text { Ricardo Hydra } \\
\text { (direct injection) }\end{array}$ & $\begin{array}{l}1 \text { cylinder } \\
(449 \mathrm{cc})\end{array}$ & 19.8:1 & - & - \\
\hline $\begin{array}{l}\text { CSOME, SBOME, RSOME, } \\
\text { POME, WCOME } \\
\text { (Wu et al., 2009) }\end{array}$ & $\begin{array}{l}\text { Cummins ISBe6 } \\
\text { (direct injection) }\end{array}$ & $\begin{array}{l}6 \text { cylinders } \\
(5900 \mathrm{cc})\end{array}$ & 17.5:1 & 136 & 2500 \\
\hline $\begin{array}{l}\text { SBOME, PNOME, COME, } \\
\text { SFOME, RSOME, POME, } \\
\text { PKOME, WFOME } \\
\text { (Lin et al., 2009) }\end{array}$ & $\begin{array}{l}\text { Yanmar-TF110F } \\
\text { (direct injection) }\end{array}$ & $\begin{array}{l}1 \text { cylinder } \\
(584 \mathrm{cc})\end{array}$ & 17.9:1 & 8.10 & 2400 \\
\hline $\begin{array}{c}\text { CaOME, WFOME } \\
\text { (Ozsezen et al., 2010) }\end{array}$ & $\begin{array}{l}\text { Ford 6.0L Cargo } \\
\text { (direct injection) }\end{array}$ & $\begin{array}{l}6 \text { cylinders } \\
(5946.8 \mathrm{cc})\end{array}$ & $15.9: 1$ & 81.0 & 2600 \\
\hline $\begin{array}{l}\text { RSOME, SBOME } \\
\text { (Celikten et al., 2010) }\end{array}$ & $\begin{array}{c}\text { Steyr } \\
\text { (direct injection) }\end{array}$ & $\begin{array}{l}4 \text { cylinders } \\
(3141.6 \mathrm{cc})\end{array}$ & - & 46.0 & 2400 \\
\hline $\begin{array}{l}\text { Methanol and Ethanol } \\
\text { (Sayin, 2010) }\end{array}$ & $\begin{array}{l}\text { Super Star - 7710: } \\
\text { (direct injection) }\end{array}$ & $\begin{array}{l}1 \text { cylinder } \\
(770 \mathrm{cc})\end{array}$ & $17: 1$ & 7.40 & 1900 \\
\hline
\end{tabular}

${ }^{1}: \mathrm{CR}=$ compression ratio

Table 3. Weight percent of fatty acids in oil feedstock

\begin{tabular}{cccccccccc}
\hline & $* \mathrm{C} 14: 0$ & $\mathrm{C} 16: 0$ & $\mathrm{C} 16: 1$ & $\mathrm{C} 18: 0$ & $\mathrm{C} 18: 1$ & $\mathrm{C} 18: 2$ & $\mathrm{C} 18: 3$ & $\mathrm{C} 20: 0$ & $\mathrm{C} 20: 1$ \\
& & & & & & & & $\mathrm{C} 22: 0$ & $\mathrm{C} 22: 1$ \\
\hline Soybean & 0.3 & $7-11$ & $0-1$ & $3-6$ & $22-34$ & $50-60$ & $2-10$ & $5-10$ & - \\
Palm & $1-6$ & $32-47$ & - & $1-6$ & $40-52$ & $2-11$ & - & - & - \\
Rapeseed & - & $2-5$ & 0.2 & $1-2$ & $10-15$ & $10-20$ & $5-10$ & 0.9 & $50-60$ \\
Sunflower & - & 6.0 & - & 4.2 & 18.7 & 69.3 & 0.3 & 1.4 & - \\
\hline
\end{tabular}

*Length of carbon chain and number of double bonds 
General Reaction: Acid-Catalysed Pretreatment of Fatty Acids<smiles>[R]C(=O)O</smiles>

Fatty Free Acid
$\mathrm{CH}_{3} \mathrm{OH}$

Methanol

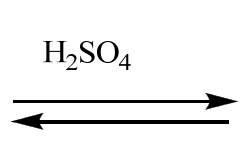<smiles>[R]C(=O)OC</smiles>

Fatty Acid Methyl Ester

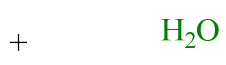

Figure 1. Acid-catalysed pre-treatment process

General Reaction: Base-Catalysed Transesterification<smiles>[R]C(=O)OCC(COC([R])=O)OC([R2])=O</smiles><smiles>[R]C(=O)OC</smiles><smiles>N#CC(O)C(O)CO</smiles><smiles>[R2]C(=O)OC</smiles><smiles>[R]C(=O)OC</smiles>

Triglyceride

Methanol

Glycerol

Methyl Esters (Biodiesel)

Figure 2. Base-catalysed transesterification process using methanol

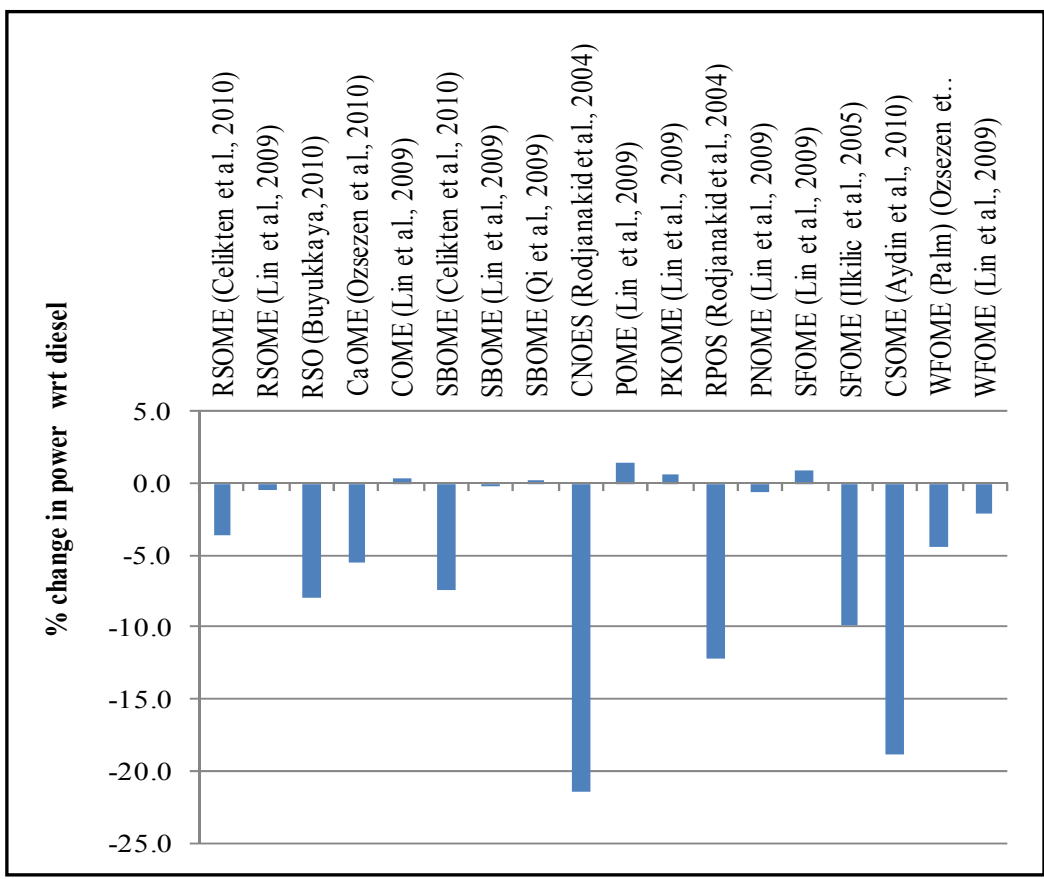

Figure 3. Comparison of average percentage change in power with different biodiesels wrt diesel 


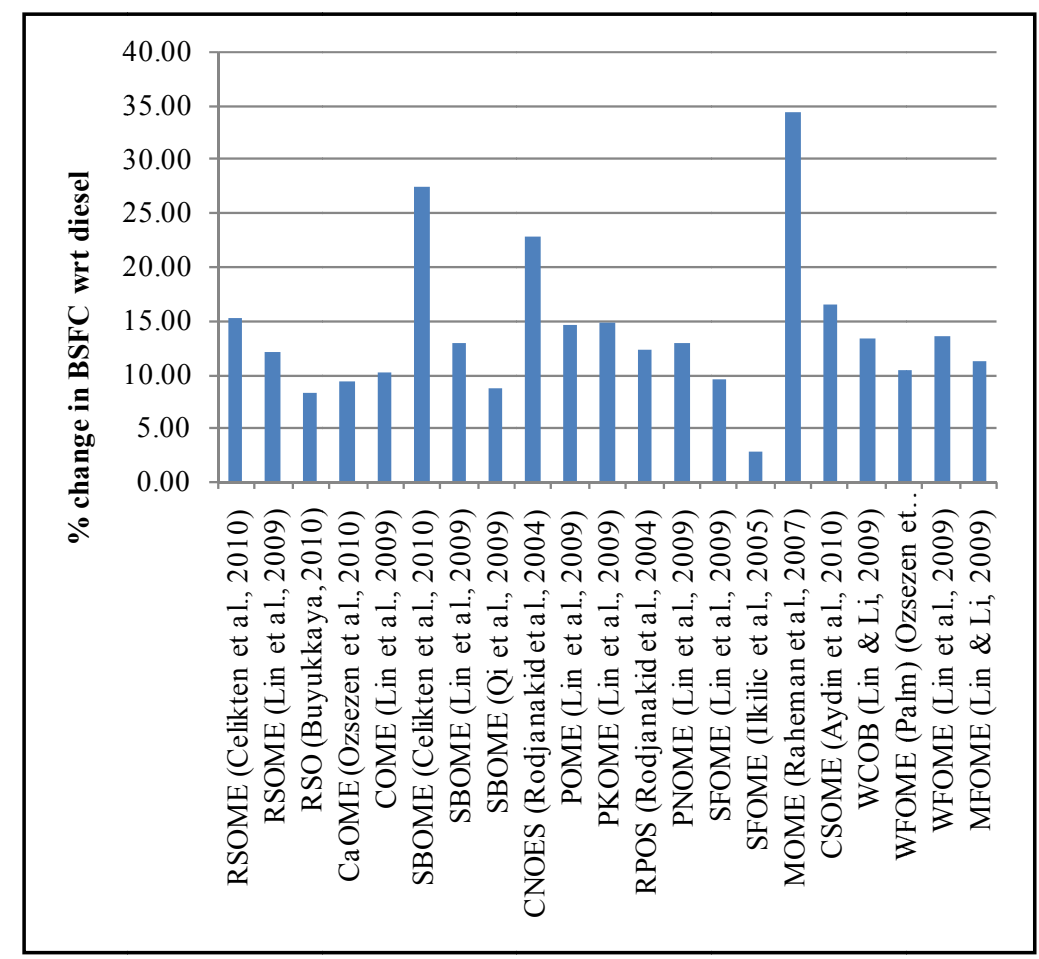

Figure 4. Comparison of average percentage change in BSFC with different biodiesels wrt diesel

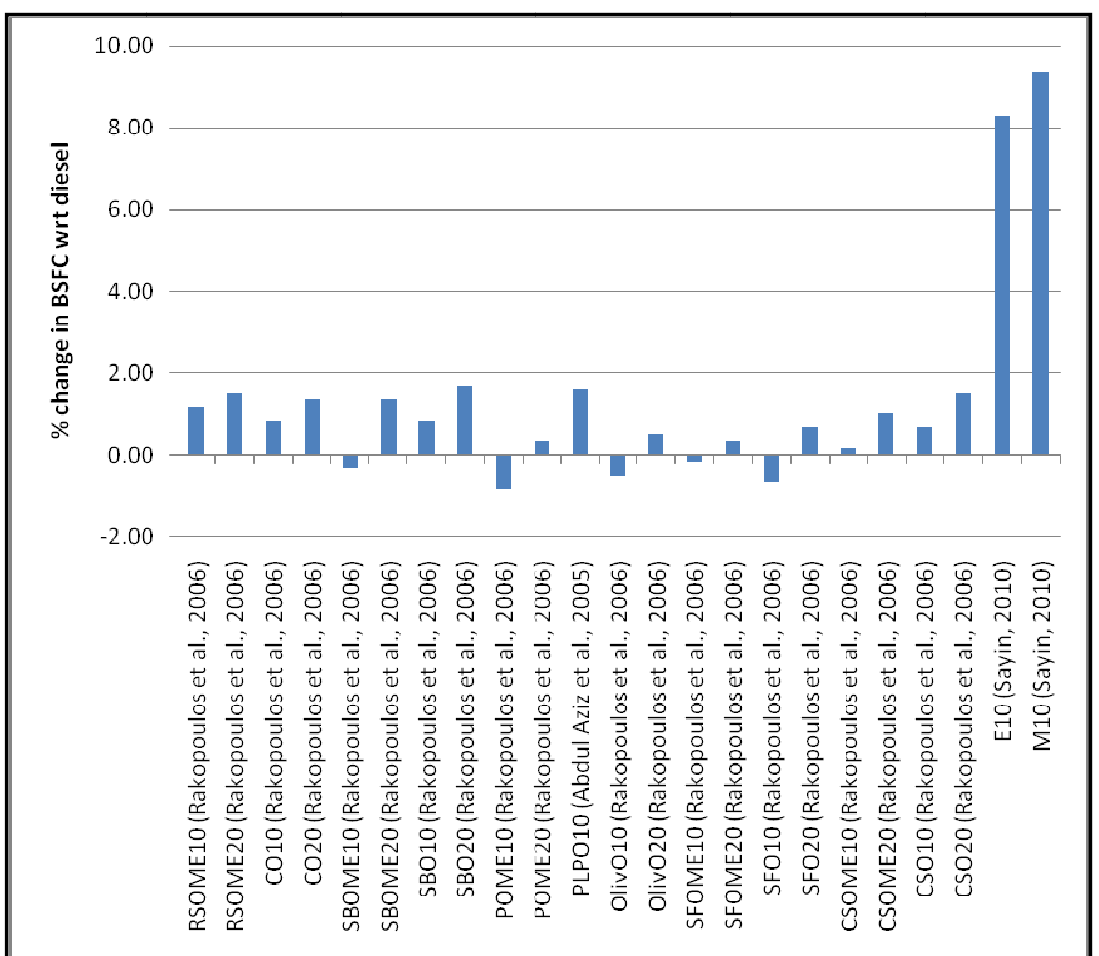

Figure 5. Comparison of average percentage change in BSFC with different blends of biodiesels wrt diesel 


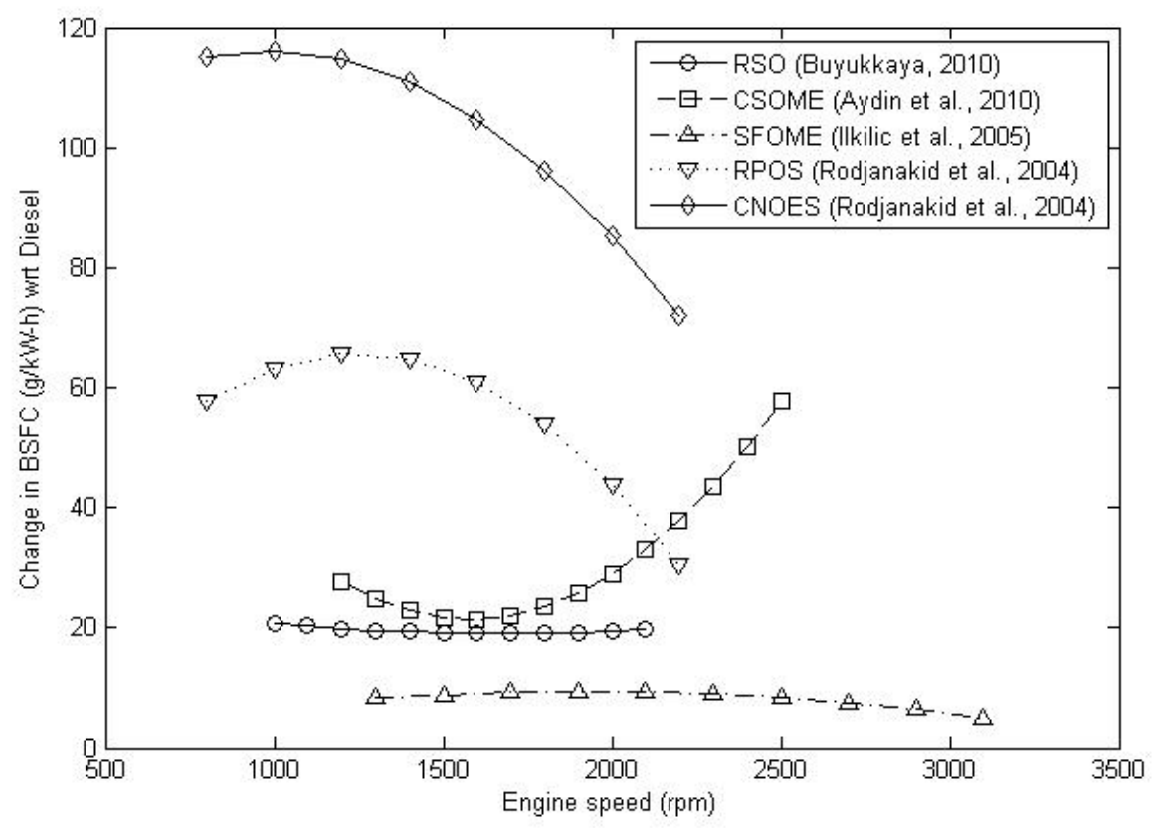

Figure 6. Comparison of change in BSFC with respect to diesel at different engine speeds for some biodiesels

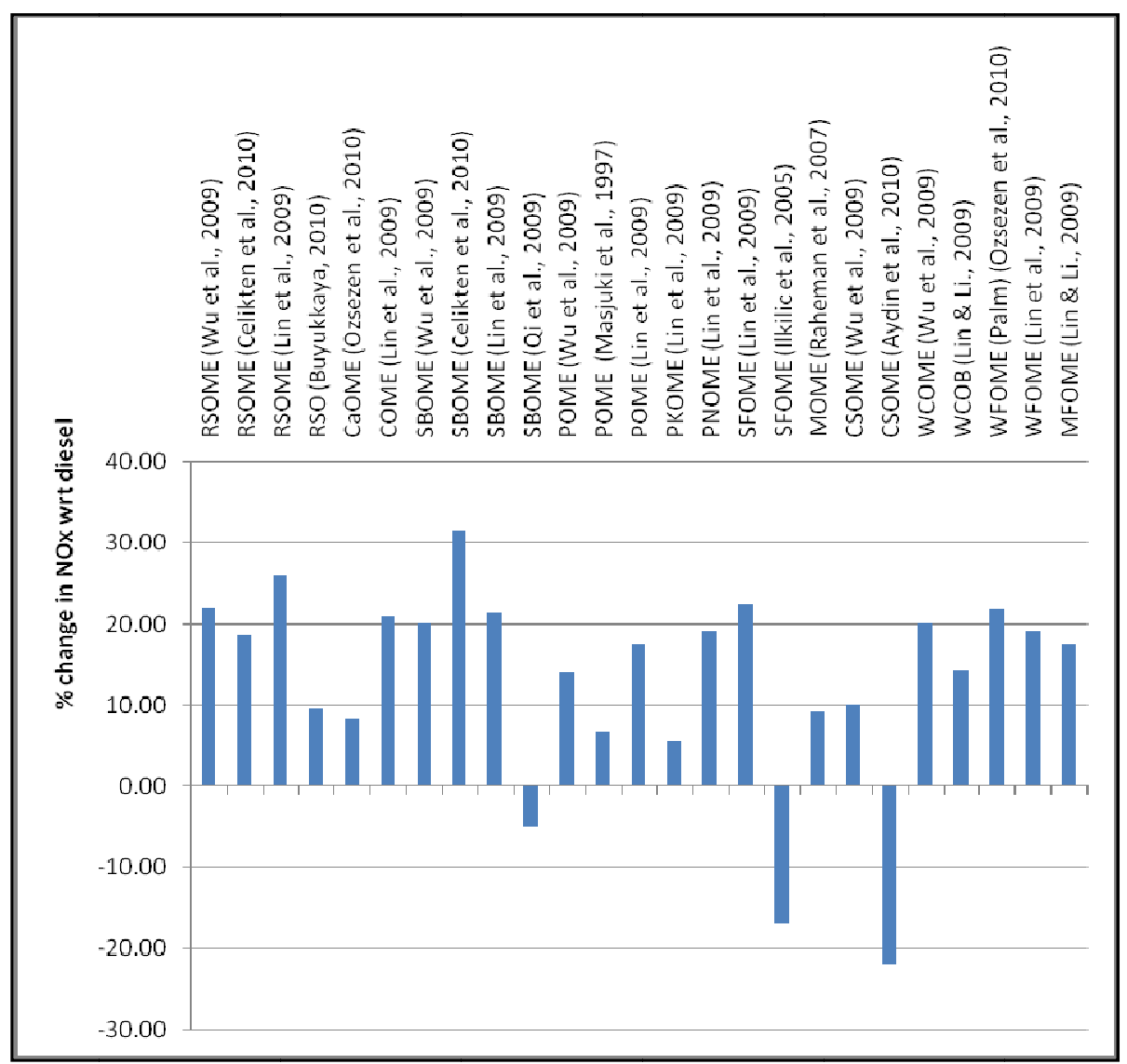

Figure 7. Comparison of average percentage change in $\mathrm{NO}_{\mathrm{x}}$ with different biodiesels wrt diesel 


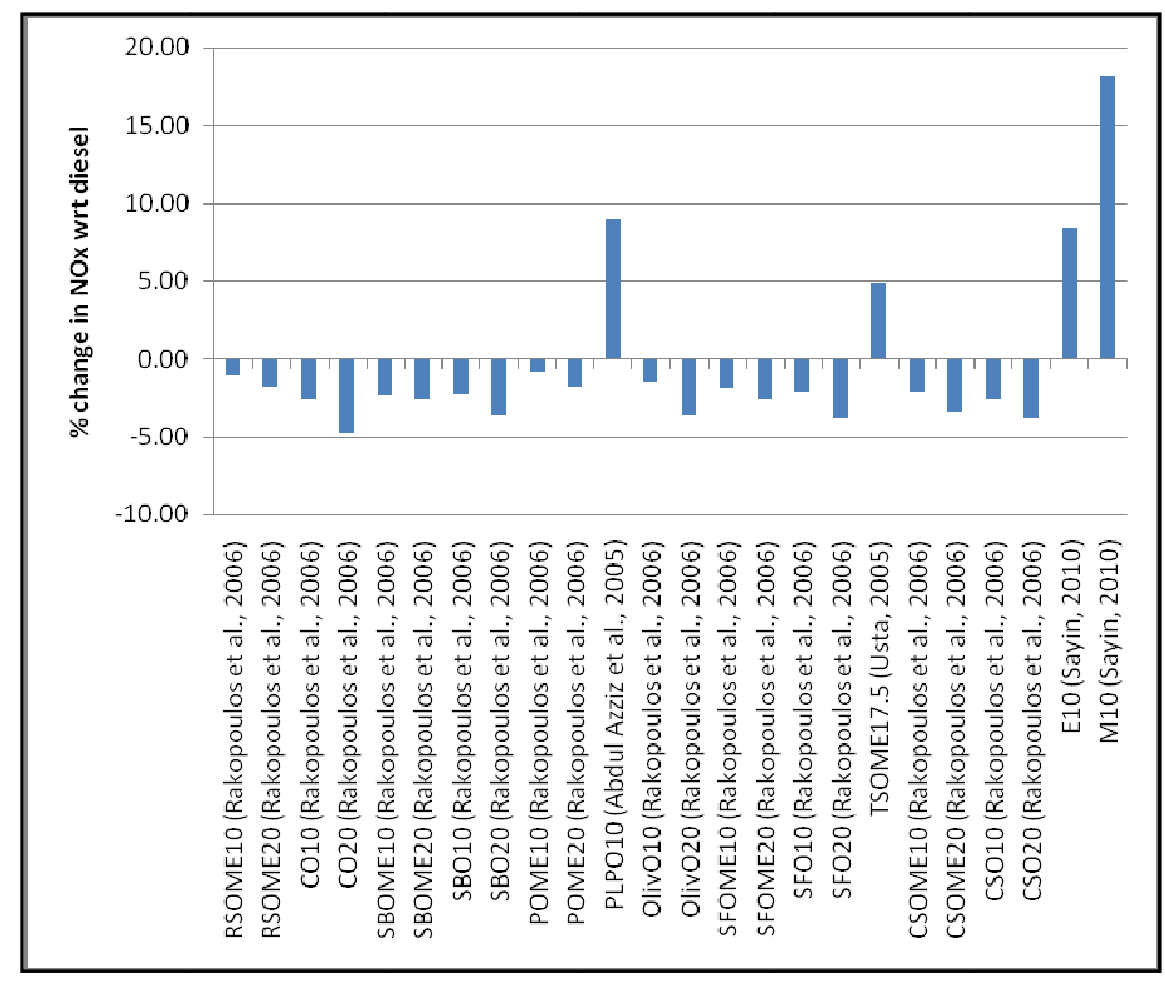

Figure 8. Comparison of average percentage change in $\mathrm{NO}_{\mathrm{x}}$ with different blends of biodiesels wrt diesel

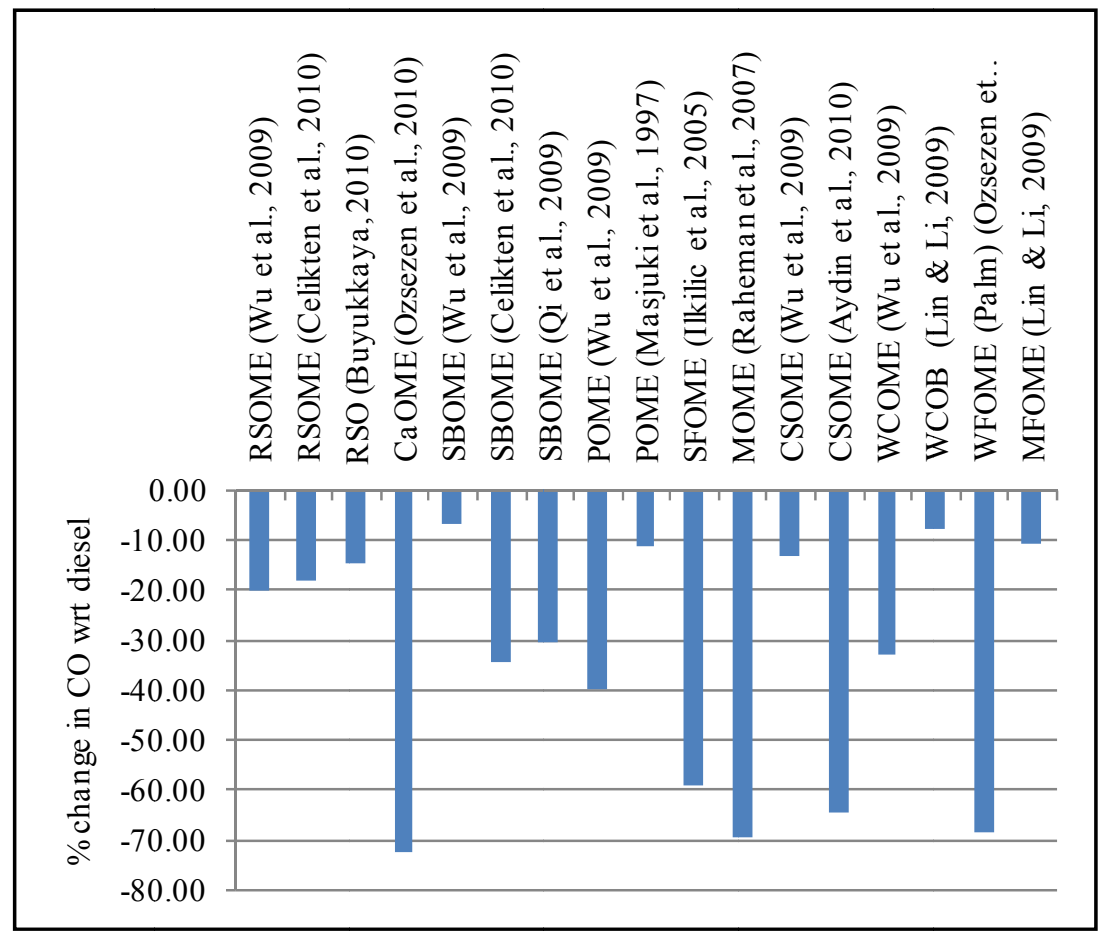

Figure 9. Comparison of average percentage change in $\mathrm{CO}$ with different biodiesels wrt diesel 


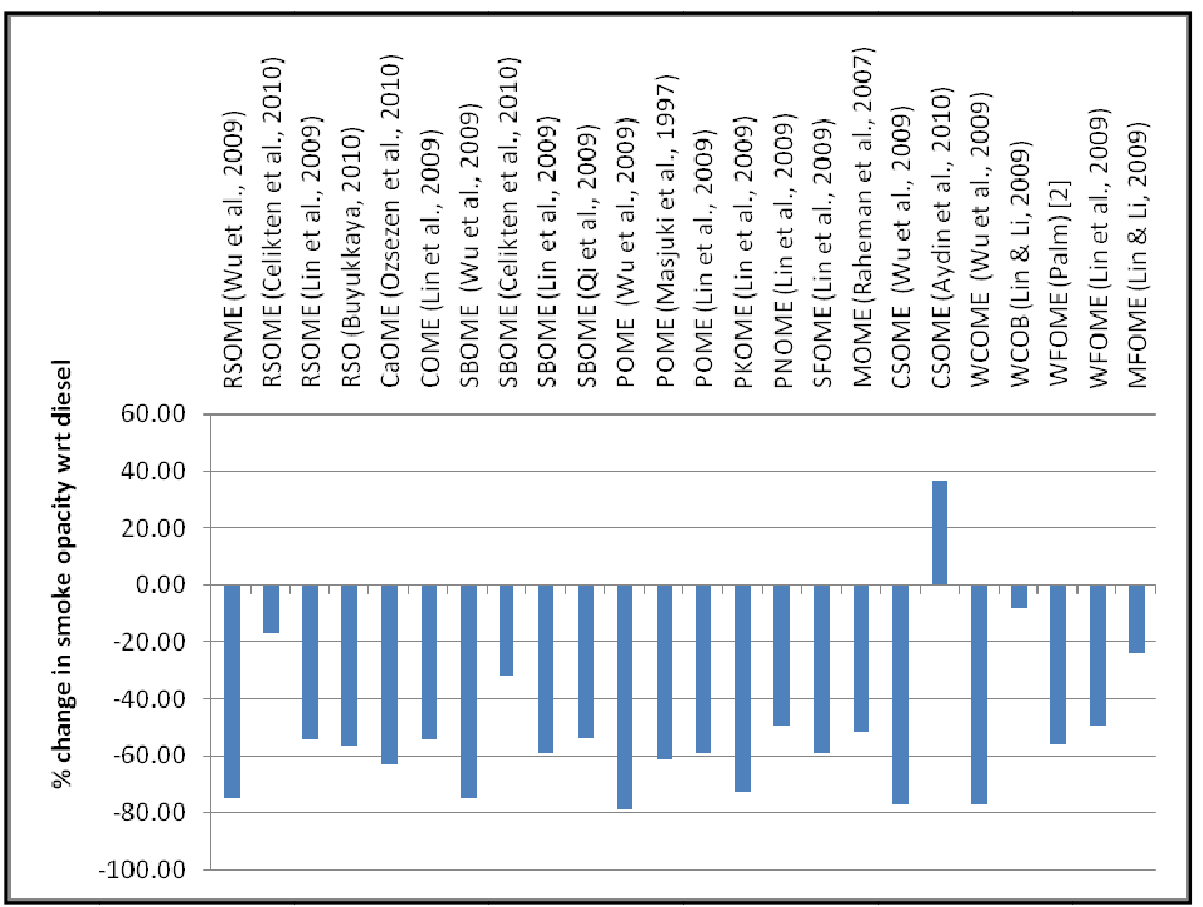

Figure 10. Comparison of average percentage change in smoke opacity with different biodiesels wrt diesel

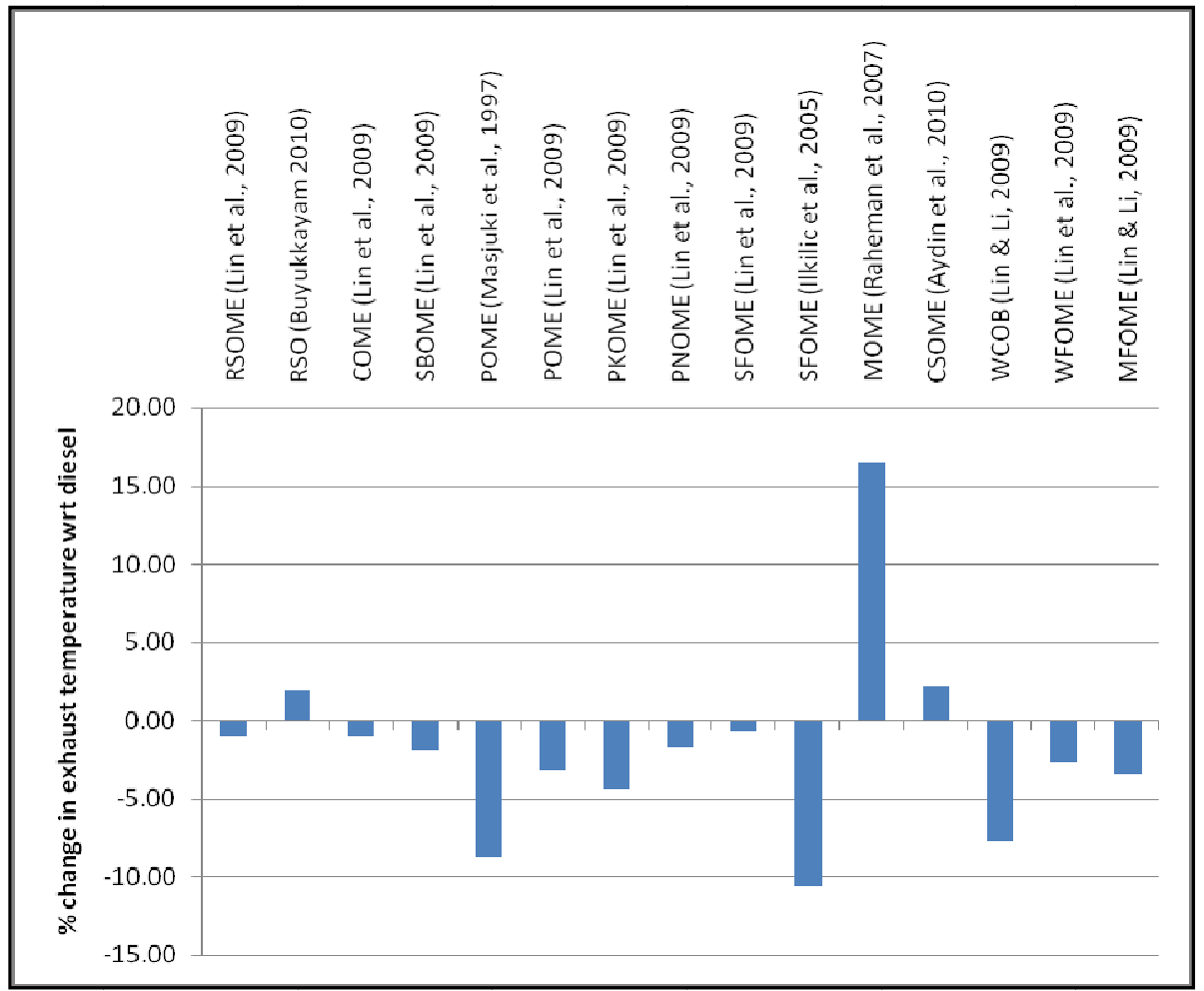

Figure 11. Comparison of average percentage change in exhaust gas temperature with different biodiesels wrt diesel 